\title{
Strategi Guru dan Keterlibatan Orangtua dalam Pemahaman Konsep Sains Anak Selama Covid-19
}

\author{
Dara Zulaiha', Arif Rohman' \\ Pendidikan Anak Usia Dini, Universitas Negeri Yogyakarta \\ DOI: $\underline{10.31004 / \text { obsesi.v5i2.816 }}$
}

\begin{abstract}
Abstrak
Penelitian ini bertujuan untuk meninjau strategi guru dan keterlibatan orang tua dalam upaya pemahaman konsep sains anak TK Islam Al-Azhar 41 Palembang selama pandemi melalui pembelajaran daring. Penelitian ini menggunakan metode survei dengan jenis pendekatan deskriptif kuantitatif. Teknik pengumpulan data melalui wawancara dengan dua orang guru dan penyebaran angket kepada 31 orang tua. Hasil penelitian menunjukkan bahwa strategi guru dalam mempersiapkan pembelajaran sains seperti; mengadakan sosialisasi guru dengan melibatkan orang tua dan melakukan briefing antar sesama guru dengan mempelajari video tutorial sains ternyata dapat menambah rasa percaya diri guru dalam mengajarkan sains serta menjadi lebih kreatif memilih konten sains yang tepat. Disamping itu, ditemukan lebih dari $50 \%$ orang tua terlibat dalam pembelajaran sains anak, mulai dari persiapan, proses, dan evaluasi. Kerja sama antara guru dan orang tua dalam pemahaman konsep sains anak mampu membantu anak berpikir lebih kritis, memecahkan masalah, dan mengetahui sebab-akibat dari sesuatu yang diamati di lingkungannya.
\end{abstract}

Kata Kunci: strategi guru; keterlibatan orang tua; pemahaman konsep sains anak

\begin{abstract}
This study aims to review teacher strategies and parental involvement in the effort to understand the concept of science in Al-Azhar 41 Palembang Kindergarten children during the pandemic through online learning. This study used a survey method with a quantitative descriptive approach. Data collection techniques through interviews with two teachers and distributing questionnaires to 31 parents. The results showed that the teachers' strategies in preparing science learning such as; holding teacher outreach by involving parents and conducting briefings among teachers by studying science video tutorials can actually increase the teacher's confidence in teaching science and be more creative in choosing the right science content. In addition, it was found that more than $50 \%$ of parents are involved in children's science learning, starting from preparation, processing, and evaluation. Cooperation between teachers and parents in understanding children's science concepts is able to help children think more critically, solve problems, and find out the cause and effect of something observed in their environment.
\end{abstract}

Keywords: teacher strategy; parent involvment; understanding the child's concept of science

Copyright (c) 2020 Dara Zulaiha, Arif Rohman.

$\triangle$ Corresponding author:

Email Address : darazulaiha6@gmail.com (Perumda Km 7, Palembang)

Received 17 October 2020, Accepted 31 October 2020, Published 4 November 2020 


\section{PENDAHULUAN}

Faktor kognitif berperan sangat penting bagi keberhasilan anak dalam belajar. Dalam sebagian besar kegiatannya, mengingat dan berpikir merupakan sesuatu yang selalu dihubungkan dengan pemecahan masalah dalam kehidupan sehari-hari anak. Kemampuan anak seperti merancang, mengingat, dan mencari penyelesaian masalah merupakan suatu proses dari pengembangan kognitif (Mustofa, 2016). Dalam kompetensi dan hasil belajar yang diharapkan adalah anak memiliki kemampuan berpikir secara logis, berpikir kritis, dapat memberi alasan, mampu memecahkan masalah, dan menemukan hubungan sebab akibat dari permasalahan yang dihadapi (Yamin \& Sanan, 2013). Adapun pembelajaran yang dapat memfasilitasi keterampilan anak dalam hal tersebut adalah pembelajaran sains.

Sains merupakan pengetahuan tentang fenomena-fenomena tertentu yang di dapat melalui proses pengumpulan dan evaluasi informasi, serta sebagai bentuk adaptasi manusia pada lingkungannya (Khaeriyah et al., 2018). Sementara sains dalam prasekolah didefinisikan sebagai semua kegiatan pengamatan langsung yang dilakukan oleh anak-anak dalam interaksi sosial yang kemudian berkontribusi pada minat dan pemahaman anak yang muncul secara perlahan tentang alam (Broström, 2015). Bidang penting dari kompetensi sains di prasekolah adalah memahami konsep-konsep dasar sains yang disebut sebagai pengetahuan konten sains. Konten sains hendaknya didasarkan pada fenomena yang diamati dan dialami langsung oleh anak dalam kehidupannya sehari-hari (Guo, Ying, 2015). Artinya pengayaan dalam pembelajaran sains harus di mulai dari lingkungan yang terdekat dengan anak dan bersifat konkret.

Dari hasil penelitian sebelumnya telah banyak yang menyimpulkan bahwa anak pada usia prasekolah telah mampu menerima pembelajaran sains karena sifatnya yang menuntut anak untuk selalu ingin tahu tentang dunia. Kesiapan sains didefinisikan sebagai kemampuan yang muncul untuk mengembangkan pengetahuan ilmiah tentang dunia alam dan fisik, mempelajari keterampilan dan metode ilmiah, mengembangkan keterampilan penalaran serta pemecahan masalah (Bustamante et al., 2018). Keterampilan proses sains dasar harus dikuasai sebelum seseorang dapat mendominasi keterampilan proses sains yang terintegrasi. Pandangan ini di dukung oleh Piaget, anak dapat berpikir abstrak dalam keterampilan proses sains yang terintegrasi apabila telah menguasai keterampilan proses sains dasar (Nurkholisoh, 2020). Pernyataan tersebut memberi pemahaman bahwa sebelum anak mampu berpikir abstrak tentang sains, maka mereka harus memperluas pengalaman terkait dengan suatu peristiwa yang ditemui dalam kehidupan nyata guna membantu mereka untuk mengembangkan konsep yang dapat diterima oleh nalar.

Kemampuan anak dalam memahami konsep sains menjadi bagian yang terpenting dalam pembelajaran sains. Pemahaman konsep sains pada anak usia dini mengandung makna yang sangat sederhana, karena pembelajaran sains yang dimaksud bukanlah berisi rumus ataupun teori. Sehingga dalam praktiknya anak hanya membutuhkan suatu objek nyata yang dapat diamati kemudian mencari tahu sebab akibat dari peristiwa tersebut dengan membangun pemahamannya berdasarkan pengetahuan dan pengalaman sebelumnya. Anak usia dini memiliki kecenderungan untuk mengamati dan berpikir tentang sifat serta memiliki keinginan untuk belajar sains lebih tinggi daripada keinginan untuk belajar membaca dan menulis, matematika, seni, dan bidang sosial (Akçay, 2016). Oleh karena itu, keterampilan sains perlu diperkenalkan sejak dini kepada anak, karena pengetahuan dan keterampilan dasar seperti mengamati fakta dan peristiwa, mencari jawaban atas pertanyaan, dan mendapatkan pemahaman terkait konsep pengetahuan dasar anak akan terbentuk pada masa ini, sehingga pengalaman tersebut akan berpengaruh terhadap akademik anak kelak. Pengembangan akademik yang dimaksud dikaitkan dengan kemampuan anak untuk memahami konsep, keterampilan memecahkan masalah secara ilmiah, serta mengembangkan sikap analitis dan kritis saat memproses informasi (Dogan, Y. \& Simsar, 2018; Qonita, E. S. \& Mulyana, 2017). Selain itu juga berguna untuk mempersiapkan mental anak dalam bersaing secara global di tengah kemajuan teknologi. 
Selama praktik kegiatan sains di sekolah, pengaturan yang nyaman harus dipenuhi agar anak berkesempatan untuk menyelidiki, membuat prediksi dan mengomunikasikan tentang subjek, memuaskan rasa keingintahuannya, serta mencari hubungan sebab akibat dari suatu peristiwa. Ketika guru memberi akses kepada anak untuk mengaktifkan semua indranya termasuk penciuman, sentuhan, dan rasa saat mengamati objek, maka informasi yang diperoleh anak akan semakin mudah untuk ia pahami (Dogan, Y. \& Simsar, 2018).

Pada pembelajaran sains di sekolah, anak diharapkan mampu memenuhi capaian kurikulum sebagaimana indikator pemahaman konsep sains, yaitu; (1) belajar dan pemecahan masalah, diantaranya; anak menunjukkan kegiatan eksploratif dan menyelidik (misalnya, apa yang terjadi ketika api disiram dengan air); menyesuaikan pengetahuan dan pengalaman yang ada ke dalam situasi baru; serta menemukan solusi dan menyelesaikan masalah dengan cara kreatif; (2) berpikir logis, diantaranya; anak mampu mengenal konsep besar-kecil, banyak-sedikit, panjang-pendek, berat-ringan, tinggi-rendah dengan menggunakan alat ukur yang tidak baku; mengenal sebab akibat dari peristiwa yang diamati (misalnya; energi panas dari matahari dapat mengeringkan baju yang dijemur) (Permendikbud Indonesia Nomor 146, 2014).

Namun, kemunculan pandemi covid-19 yang tidak disangka-sangka menimbulkan permasalahan baru, khususnya bagi para pendidik yang diharuskan untuk memenuhi tantangan pembelajaran melalui jarak jauh/daring dengan murid mereka. Hal ini dialami merata oleh seluruh pendidik dari jenjang prasekolah hingga ke tingkat perguruan tinggi. Disamping disebut sebagai bencana, wabah covid-19 juga memberi keuntungan bagi para pendidik untuk menggunakan keahlian, daya tanggap, dan kreativitas mereka dalam menciptakan strategi pembelajaran yang efektif. Tidak dapat disangkal bahwasanya semua guru dituntut untuk mengembangkan pengetahuan, keterampilan, dan kepercayaan diri mereka saat melakukan pengajaran online. Permasalahan ini memunculkan faktor baru yang menyebabkan anak kesulitan untuk berinteraksi langsung dengan guru. Bayangkan saja betapa sulitnya guru memberi pengawasan kepada anak saat melakukan kegiatan eksperimen melalui daring.

Ada banyak faktor yang menjadi penghambat anak untuk memahami konsep sains yang diterima dari guru, salah satunya sains sering dianggap sebagai pelajaran yang cukup rumit oleh pihak sekolah, sehingga tidak mendapat perhatian yang sebanding dengan pelajaran lainnya. Selanjutnya adalah faktor kurangnya pengetahuan dan pengalaman guru dalam pelatihan di bidang sains sebagaimana yang ditegaskan oleh peneliti lain bahwa guru sering memiliki pengetahuan konten yang tidak mencukupi atau ide-ide alternatif tentang topik sains (Kavalari, P., 2012), strategi dan metode yang kurang kreatif, permasalahan waktu yang sulit di sesuaikan dengan singkatnya jadwal pembelajaran di kelas, serta sedikitnya bahan pendukung dalam penerapan sains menjadi penyebab anak kehilangan kesempatan untuk memperoleh pembelajaran sains. Rendahnya kepercayaan pendidik juga menjadi salah faktor yang berpengaruh, karena dapat menghambat pendidik dalam memfasilitasi pengalaman pembelajaran sains yang berkualitas, sehingga hasil pemerolehan yang didapat anak tidak sesuai dengan capaian kurikulum (Gerde, H. K., 2013).

Tetapi akan berbeda permasalahannya jika yang menjadi penghambat anak dalam memahami konsep sains adalah faktor sulitnya akses pembelajaran yang dilakukan dari jarak jauh (daring), bukan karena kurangnya fasilitas ataupun faktor pendukung lainnya. Sehingga menyebabkan guru mengalami sedikit kesulitan untuk menilai pemahaman konsep sains yang diterima oleh anak. Peneliti meninjau permasalahan yang relevan dengan kasus ini di TK Islam Al-Azhar 41 di Palembang. Pembelajaran sains di sekolah tersebut tetap dilakukan meskipun via daring. Maka atas dasar inilah peneliti tertarik untuk mengetahui lebih jauh tentang strategi yang dilakukan oleh guru dan keterlibatan orang tua dalam upaya pemahaman konsep sains anak. 


\section{METODOLOGI}

Penelitian ini menggunakan metode survei jenis pendekatan deskriptif kuantitatif. Penelitian deskriptif bertujuan untuk mendeskripsikan suatu kondisi subjek di lapangan berdasarkan keadaan faktual agar mendapatkan implikasi dari suatu masalah yang diteliti (McMillan \& Schumacher, 2001). Teknik pengumpulan data berupa wawancara terstruktur, penyebaran angket, dan dokumentasi. Wawancara dilakukan kepada 2 orang guru kelompok B, angket disebarkan secara online kepada 31 orang tua anak, serta dokumentasi kegiatan pembelajaran sains anak kelompok B (usia 5-6 tahun). Setelah data dikumpulkan, selanjutnya menganalisis data dengan teknik editing (koreksi data), coding (memberi tanda pada data yang terdiri dari beberapa kategori dengan berupa angka), scoring (memberi nilai sesuai kriteria yang telah ditetapkan), dan tabulating (penjumlahan data).

Penelitian ini menggunakan Skala Likert untuk mengukur tingkat keterlibatan orang tua pada upaya pemahaman konsep sains anak dengan total item pernyataan berjumlah 20 yang diberikan kepada responden dengan pilihan jawaban yang disediakan, diantaranya Tidak Pernah (TP); Kadang-kadang (KK); Sering (SR); dan Selalu (SL) dengan bobot 1, 2, 3, 4. Teknik analisis data menggunakan metode statistik deskriptif untuk mengetahui strategi seperti apa yang dilakukan guru dan bagaimana keterlibatan orang tua di TK Islam Al-Azhar 41 dalam upaya pemahaman konsep sains yang diterima oleh anak selama pembelajaran melalui daring. Strategi guru akan dijabarkan berdasarkan hasil wawancara, sedangkan untuk mencari tahu sejauh mana keterlibatan orang tua yakni melalui analisis data dengan menghitung rata-rata jawaban setiap orang tua dari angket yang disebarkan. Setelah diketahui skor maksimal dari semua pernyataan yang dipilih oleh masing-masing responden, maka selanjutnya disesuaikan dengan hasil dokumentasi kegiatan anak selama pembelajaran sains melalui daring. Alur penelitian secara ringkas disajikan pada bagan 1.

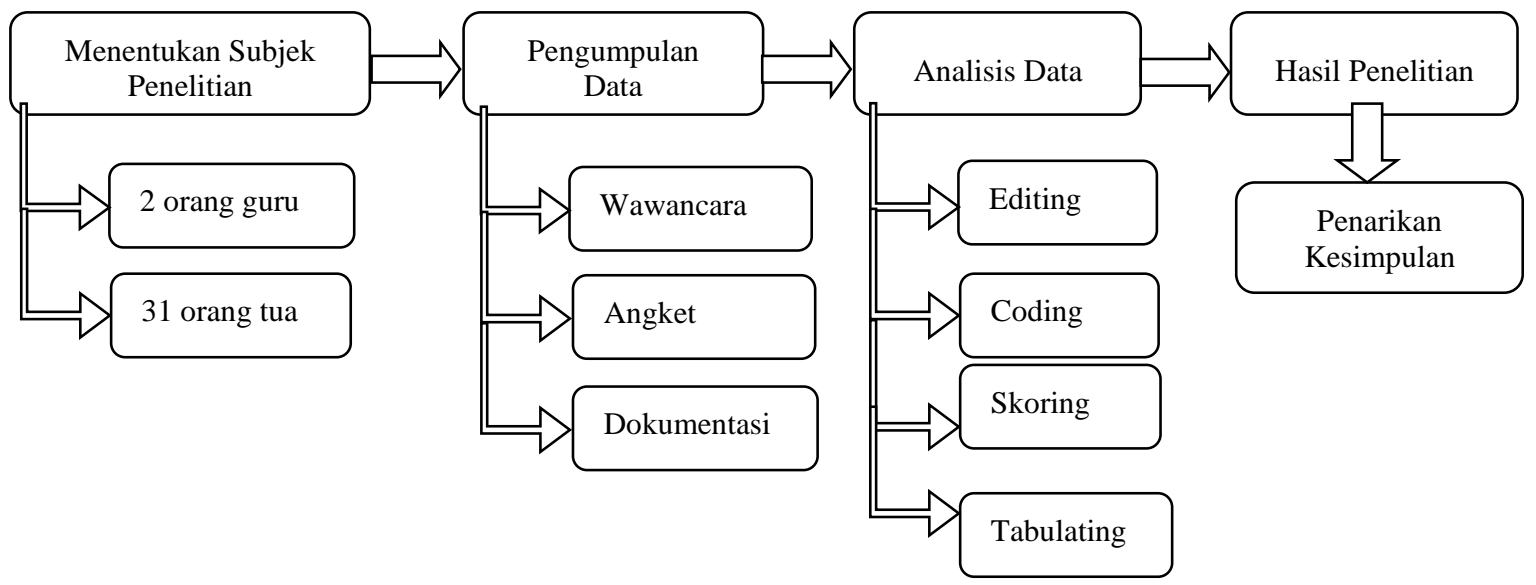

Bagan 1. Alur Penelitian

\section{HASIL DAN PEMBAHASAN}

\section{Hasil Wawancara Strategi Guru}

Berdasarkan hasil dari wawancara kepada dua orang guru, ditemukan bahwa strategi yang dilakukan guru tidak ada perbedaan secara signifikan dengan strategi yang biasa dilakukan oleh TK lain pada umumnya. Metode pembelajaran sains tetap dilakukan dengan cara demonstrasi. Namun, meskipun demikian tentu ada persiapan guru dalam pelaksanaan pembelajaran sains selama covid-19. TK Islam Al-Azhar 41 tetap melakukan pembelajaran sains melalui sistem daring dengan berbantuan aplikasi zoom. Kegiatan eksperimen dilaksanakan di setiap hari senin, dalam satu bulan dilakukan sebanyak empat kali percobaan sains. Durasi percobaan sains rata-rata berkisar antara 15-25 menit.

Setiap awal tahun pelajaran, para guru bersama dengan orang tua mengadakan sosialisasi melalui program PAT (Pertemuan Awal Tahun). Dalam pertemuan ini, guru dan orang tua membuat perencanaan pembelajaran sains yang didasarkan pada kebutuhan dan 
usia anak. Dengan cara ini, maka orang tua bisa turut andil untuk terlibat dalam kegiatan pembelajaran anak, khususnya selama pandemi. Orang tua diberi pemahaman tentang keterlibatan selama anak melakukan percobaan sains, di mulai dari menyiapkan alat dan bahan, proses eksperimen, hingga penilaian sains dari rekaman yang didokumentasikan orang tua untuk dilaporkan kepada guru. Disamping itu, jauh hari sebelum memulai pembelajaran sains, para guru melakukan briefing tentang percobaan yang akan dilakukan. Mereka biasanya dikirim panduan khusus penerapan percobaan sains berupa video dari TK pusat di kota Jakarta. Hasil temuan dari penelitian (Saçkes, 2012) mengatakan bahwa guru yang memiliki keterampilan di bidang sains dari hasil pelatihan akan lebih sering mengajarkan konsep sains di PAUD. Sehingga, peluang anak untuk belajar sains akan lebih mudah karena guru diyakini memiliki kemampuan mengajar sains dengan konsep yang telah dikhususkan untuk diajarkan pada anak. Ketersediaan bahan ajar yang berhubungan dengan sains juga diyakini dapat mendorong para guru untuk mengajarkan konten sains lebih sering.

Untuk menambah wawasan tentang konsep sains yang akan diajarkan, guru senantiasa berinisiatif mencari referensi dari berbagai sumber, seperti; youtube atau google. Melalui cara demikian, guru mengaku bahwa tingkat kepercayaan diri mereka lebih meningkat.

“...semakin banyak seseorang mencari pengetahuan, maka akan semakin membuat mereka lebih percaya diri," ungkap narasumber guru DN.

Pengetahuan tersebut dapat membantu guru dalam menciptakan ide-ide yang akan dijadikan konten dalam pelaksanaan kegiatan sains yang mungkin dapat berbeda di setiap pertemuan.

Dalam kegiatan eksperimen, guru mendemonstrasikan terlebih dahulu langkahlangkah percobaan sains, kemudian baru diikuti oleh anak-anak. Dalam proses ini, anak terlihat begitu antusias saat melakukan percobaan sains. Pengamatan ini ternyata sejalan dengan pendapat guru ketika diwawancarai tentang seberapa antusias anak mengikuti pembelajaran sains selama pembelajaran berlangsung dari jarak jauh/daring.

“Tentu anak sangat antusias sekali ya, mereka terlibat langsung untuk mengeksplor kegiatan sains itu... apalagi selama covid ini pembelajaran yang paling ditunggu oleh anak adalah kegiatan eksperimen, karena kegiatan tersebut dapat mengobati rasa kebosanan anak selama mereka harus mengikuti pembelajaran dari rumah...". (Kutipan narasumber DN)

Selain menarik, pembelajaran sains bisa membangkitkan minat anak untuk selalu ingin tahu tentang apa yang ia amati, serta mengajarkan anak untuk menghargai keanekaragaman yang ada di sekitarnya. Ketika anak memperoleh informasi tentang alam, maka akan tumbuh rasa memiliki dalam diri anak, sehingga mereka akan cenderung melindungi dan menghargai alam (Olcer, 2017). Dengan demikian, anak tidak hanya mendapat pengalaman dari pembelajaran sains, tetapi juga dapat membentuk perilaku yang bernilai positif di dalam dirinya.

\section{Hasil Analisis Keterlibatan Orang Tua}

Untuk memahami bagaimana keterlibatan orang tua dalam upaya pemahaman konsep sains anak, maka peneliti menyebarkan angket yang berisi 20 pernyataan yang dibagi menjadi 3 bagian. Bagian 1 berisi pernyataan tentang keterlibatan orang tua dalam persiapan kegiatan sains anak di rumah; bagian 2 berisi tentang keterlibatan orang tua dalam proses kegiatan sains anak; adapun bagian 3 berisi pernyataan tentang keterlibatan orang tua dalam evaluasi kegiatan sains anak. Pernyataan ini diisi oleh sebanyak 31 responden. Dalam artikel ini peneliti hanya fokus pada penjelasan hasil bagian 2 yang berisi tentang keterlibatan orang tua dalam proses kegiatan sains anak. Adapun penjelasan mengenai hasilnya secara lebih rinci akan dijabarkan berdasarkan gambar 1 . 


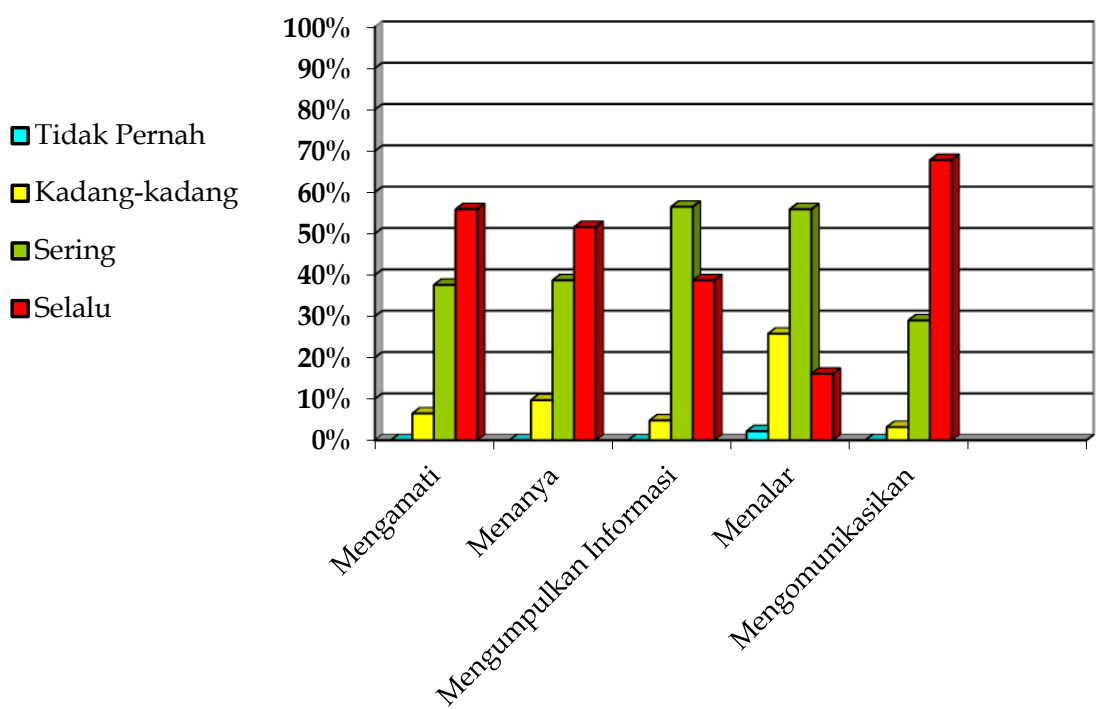

Gambar 1. Keterlibatan Orang Tua dalam Proses Kegiatan Sains Anak

Berdasarkan hasil analisis bagian 2 tentang keterlibatan orang tua dalam proses kegiatan sains anak, maka peneliti membagi soal menjadi 5 bagian, yaitu; (1) mengamati; (2) menanya; (3) mengumpulkan informasi; (4) menalar; dan (5) mengomunikasikan. Pada setiap bagian terdiri dari beberapa soal.

Bagian 1 (mengamati) berisi 3 soal, diantaranya; (a) saya memberi kesempatan kepada anak untuk mengamati alat-alat dan bahan-bahan yang diperlukan sebelum memulai kegiatan eksperimen; (b) saya memberi kesempatan kepada anak untuk menggunakan panca indera nya (penglihatan, penciuman, pendengaran, sentuhan, dan perasa) saat melakukan eksperimen; (c) saya memberi kesempatan kepada anak untuk mengamati objek dengan menyebutkannya berdasarkan bentuk, warna, tekstur, sifat, fungsi, dan bunyi nya. Dari ketiga soal tersebut, didapati hasil analisis rata-rata sebesar 55,9\% responden menjawab "selalu", $37,6 \%$ responden menjawab "sering", 6,5\% responden menjawab "kadang-kadang".

Peneliti mengambil contoh salah satu kegiatan eksperimen anak yang bertema "Bakteri Go Away". Pada kegiatan awal, orang tua anak mempersiapkan alat dan bahan yang diperlukan, seperti; air secukupnya di dalam piring, lada, dan sabun cuci piring. Dalam prosesnya, rata-rata orang tua meminta anak untuk mengamati terlebih dahulu alat dan bahan yang akan digunakan pada percobaan ini, sebagian orang tua memberi kesempatan kepada anak untuk merasakan tekstur dari bahan yang ada, seperti lada dan sabun cuci piring. Selain itu orang tua juga meminta anak untuk mencium bau lada dan sabun cuci piring. Orang tua menjelaskan bahwa lada bisa didapat dengan mudah di pasar, karena ibu biasanya menggunakan lada untuk memasak sayur sop. Begitu juga dengan sabun cuci piring, anak bisa menggunakannya untuk mencuci alat mainan mereka selain untuk mencuci piring.

Selanjutnya pada bagian 2 (menanya) berisi 2 soal, diantaranya; (a) saya memberikan pertanyaan sederhana saat anak melakukan eksperimen; (b) saya menjawab pertanyaan anak ketika ia ingin tahu tentang sesuatu. Dari dua soal tersebut, didapati hasil analisis rata-rata sebesar 51,6\% responden menjawab "selalu", 38,7\% responden menjawab "sering", 9,7\% responden menjawab "kadang-kadang". Dalam hal ini, sebagian orang tua memberi pertanyaan sederhana kepada anak tentang warna apa saja yang ada pada bahan-bahan yang ia amati. Selanjutnya dalam prosesnya, ketika anak menuangkan air ke dalam piring, maka saat itu ada anak yang bertanya, "mengapa air tidak bisa kita genggam?", orang tua memberi penjelasan kepada anak bahwa air memiliki wujud cair, itulah mengapa air tidak bisa digenggam. Sifat air itu selalu mengikuti bentuk dari wadahnya, misalnya ketika air kita tumpahkan ke dalam gelas panjang, maka bentuknya juga seolah-olah akan memanjang sebagaimana bentuk gelas. 
Pada bagian 3 (mengumpulkan informasi) berisi 2 soal, diantaranya; (a) saya memberikan fasilitas berupa buku/internet untuk anak belajar tentang sains (makhluk hidup, tumbuh-tumbuhan, ataupun alam semesta); (b) saya melibatkan anak untuk melakukan kegiatan sains melalui aktivitas sehari-hari di rumah (menyiram dan merawat tanaman, merawat, memelihara hewan, melihat bintang dan bulan, dan sebagainya). Dari dua soal tersebut, didapati hasil analisis rata-rata 38,7\% responden menjawab "selalu", sebesar 56,5\% responden menjawab "sering", 4,8\% responden menjawab "kadang-kadang". Saat melakukan percobaan, anak mencoba menerima segala pemahaman yang ia dapat dari penjelasan orang tuanya. Pada saat itu juga anak menghubungkan pengalamannya dengan pengamatannya saat bereksperimen.

Selama pandemi, sebagian dari orang tua sudah menyadari betapa pentingnya peran mereka untuk mengenalkan segala sesuatu yang ada di sekitar anak, meskipun hanya 38,7\% orang tua yang memberi fasilitas tentang pengetahuan sains dan melibatkan anak dalam aktivitas sehari-hari (menyiram dan merawat tanaman), namun setidaknya lebih dari 50\% orang tua sering mengajak anak mereka mengeksplorasi lingkungan untuk mengamati makhluk hidup maupun peristiwa alam, contohnya mengajak anak untuk berjemur di pagi hari sambil melihat bentuk-bentuk awan atau mengajak anak melihat tenggelamnya matahari secara langsung (sunset), dan berbagai kegiatan lainnya.

Pada bagian 4 (menalar) berisi 3 soal, diantaranya; (a) saya memberi kesempatan kepada anak untuk membandingkan beberapa objek yang diamati dengan mencari perbedaan dan persamaannya; (b) saya memberi kesempatan kepada anak untuk mengelompokkan suatu benda berdasarkan ukuran, bentuk, warna, tekstur, sifat, fungsi, atau bunyi nya; dan (c) saya memberi kesempatan kepada anak untuk mengukur suatu objek yang diamati dengan cara sederhana. Misalnya: mengukur suatu benda dengan merapatkan jari-jari anak. Contoh, ukuran penghapus kecil jika diukur dengan jari anak adalah sebesar 3 jari. Dari tiga soal tersebut, didapati hasil analisis rata-rata sebesar 16,1\% responden menjawab "selalu", sebesar $55,9 \%$ responden menjawab "sering", 25,8\% responden menjawab "kadang-kadang", dan sebesar 2,2\% responden menjawab "tidak pernah". Saat bereksperimen, ada orang tua yang bertanya, seperti; "lada itu ukurannya menurut kamu gimana?", anak menjawab, "sangat kecil sekali seperti debu." Ada juga orang tua yang bertanya kepada anak, "coba kamu pegang, kira-kira tekstur lada itu gimana, beda atau tidak sama tekstur sabun cuci piring?", anak menjawab, "berbeda, kalau lada itu halus sedangkan sabun cuci piring itu licin." Dari percobaan ini, anak memahami bahwa ternyata ketika ia mencolek sabun cuci piring menggunakan jari nya lalu di masukkan ke permukaan air yang berisi lada, maka lada-lada yang awalnya menyatu akan terpisah-pisah.

Terakhir, pada bagian 5 (mengomunikasikan) berisi 2 soal, diantaranya; (a) saya memberi kesempatan anak untuk menyampaikan hasil dari pengamatannya pada hari itu; (b) saya memberi kesempatan kepada anak untuk bercerita kepada siapa saja yang ada di lingkungannya tentang percobaan sains yang sudah ia lakukan. Dari dua soal tersebut, didapati hasil analisis rata-rata jawaban responden. Sebesar $67,8 \%$ responden menjawab "selalu", sebesar 29,0\% responden menjawab "sering", 3,2\% responden menjawab "kadangkadang". Pada akhir percobaannya, sebagian besar orang tua memberi kesempatan kepada anaknya untuk bercerita tentang hasil yang ia temukan meskipun masih dengan bantuan orang tua. Contohnya, anak menjelaskan bahwa percobaan sains "Bakteri Go Away" ini mengibaratkan bahwa lada itu layaknya seperti kuman/bakteri, oleh karena itu kita harus sering-sering mencuci tangan menggunakan sabun supaya kumannya hilang.

Secara keseluruhan hasil analisis keterlibatan orang tua dalam upaya pemahaman konsep sains anak di TK Islam Al-Azhar 41 Palembang ditunjukkan pada gambar 2. 


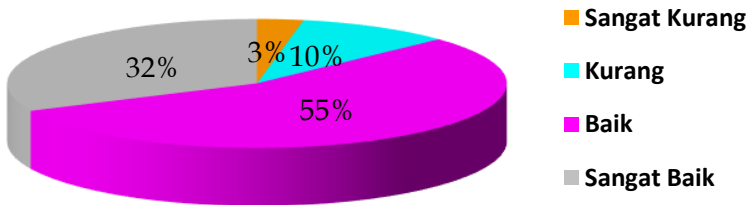

\section{Gambar 2. Keterlibatan Orang Tua dalam Pemahaman Konsep Sains Anak}

Berdasarkan hasil analisis jawaban orang tua dari angket yang disebarkan, terdapat sebanyak 55\% keterlibatan orang tua berada dalam kategori "Sangat Baik", sebanyak 32\% keterlibatan orang tua berada pada kategori "Baik", hanya ada 10\% keterlibatan orang tua berada dalam kategori "Kurang", dan 3\% keterlibatan orang tua yang berada dalam kategori "Sangat Kurang". Dengan demikian dapat dikatakan bahwa rata-rata orang tua terlibat dalam kegiatan pembelajaran sains anak mulai dari kegiatan persiapan, proses, maupun evaluasi kegiatan eksperimen anak.

\section{Pemahaman Konsep Sains Anak Usia Dini}

Pembelajaran sains lebih menitikberatkan pada pengetahuan yang didapat berdasarkan pengalaman belajar langsung melalui penemuan ilmiah. Untuk memperoleh pengetahuan menyeluruh, anak harus mampu memproses semua informasi yang mereka terima untuk dihubungkan dengan pengalaman dan pengetahuan mereka sebelumnya, ini disebut dengan pemahaman konsep (Furwati et al., 2017). Pemahaman berkaitan dengan 'belajar', artinya pengetahuan yang diperoleh tergantung pada apa yang akan diajarkan. Pembelajaran sains pada anak usia dini umumnya mencakup dua bidang pengetahuan, yaitu pengetahuan konseptual dan pengetahuan prosedural. Pengetahuan konseptual terkait dengan pembelajaran anak terhadap konten yang mencakup konsep atau cara menggambarkan suatu hubungan. Adapun pengetahuan prosedural terkait dengan metode ilmiah, yaitu kemampuan anak dalam melakukan investigasi, mengajukan pertanyaan, menganalisis data, mencari pola, dan sebagainya. Ketika anak mampu mengintegrasikan pengetahuan prosedural dan konseptual, maka dapat mengarahkan mereka pada pemahaman konseptual (Gustavsson, L., 2016; Mills, 2016).

Vygotsky menjelaskan bahwa anak mengembangkan kemampuan pemahaman konsep mereka melalui dua tingkatan, yaitu; (1) konsep sehari-hari atau yang disebut dengan hasil dari interaksi langsung dalam kehidupan sehari-hari dengan memahami tentang bagaimana melakukan sesuatu, dan (2) konsep saintifik (ilmiah), yaitu konsep yang diperoleh anak melalui akademis di sekolah (Adbo \& Vidal Carulla, 2020). Konsep sehari-hari tersebut menjadi peletak dasar untuk mempelajari konsep saintifik, sehingga saling mempengaruhi satu sama lain. Dengan demikian perlu adanya pengayaan oleh guru untuk memfasilitasi pemahaman konsep anak di sekolah melalui pembelajaran sains, karena saat melakukan eksperimen anak memiliki kesempatan untuk mengaplikasikan konsep-konsep yang telah ia peroleh ke dalam situasi kehidupan sehari-hari. Selanjutnya akan menghasilkan kemampuan anak dalam mengenal informasi baru, membangun pemahaman, dan mampu menjelaskan hubungan antar fenomena ilmiah (Widiyatmoko \& Shimizu, 2018).

Hasil temuan dari penelitian (Kuru, N \& Akman, 2017) bahwa keterampilan proses ilmiah anak-anak meningkat seiring bertambahnya usia. Hal ini berarti faktor usia berperan penting dalam menentukan tingkat pemahaman konsep sains anak karena berpengaruh pada kualitas dan kuantitas pengetahuan sains yang diperoleh anak. Selanjutnya (Guo, Ying, 2015) mengatakan pada hasil penelitiannya bahwa faktor kemampuan kognitif anak juga mempengaruhi pemahaman konsep sains anak. 
Temuan penelitian (Smolleck \& Hershberger, 2011) tentang investigasi dan miskonsepsi sains anak usia dini menjelaskan tentang strategi yang digunakan anak-anak untuk menciptakan pemahaman tentang sains dengan cara memberi kesempatan secara langsung kepada anak untuk mengeksplorasi konten sains yang sedang berlangsung. Misalnya, anak-anak menggunakan 'sentuhan' dan kategorisasi 'dapat diminum' untuk menentukan apakah suatu zat yang diamati tersebut memiliki wujud cair atau padat. Selanjutnya ketika eksperimen sedang berlangsung, anak-anak secara konsisten akan mengandalkan pengetahuan dan pengalaman mereka sebelumnya untuk mengartikulasikan pemahaman mereka. Dengan demikian, temuan ini mengingatkan pentingnya pengetahuan sebelumnya dan pengalaman masa lalu anak dalam mengembangkan konsepsi dan menghindari kesalahpahaman anak terkait dengan konsep sains.

\section{Strategi Guru dalam Upaya Pemahaman Konsep Sains Anak}

Strategi diartikan sebagai suatu rangkaian pemikiran tentang masa depan yang dibuat oleh jajaran tertentu melalui tindakan yang direfleksikan untuk mencapai tujuan sasaran (Prasojo, 2018; Siagian, 2004). Dapat dipahami bahwa strategi guru dalam upaya pemahaman konsep sains anak merupakan suatu konsep pemikiran guru yang di formulasikan dari berbagai pengalaman dan pemahamannya tentang pembelajaran sains pada anak usia dini untuk kemudian diterapkan saat proses belajar-mengajar. Diperlukan langkah-langkah yang matang bagi guru untuk memfasilitasi konteks pengajaran sains, mulai dari; perencanaan yang meliputi penyusunan program pembelajaran dan menciptakan lingkungan yang efektif; pelaksanaan melalui pengelolaan program perencanaan pembelajaran yang mengacu pada capaian perkembangan kurikulum, menentukan alat dan sumber belajar beserta metode atau strategi yang akan digunakan sehingga diharapkan anak dapat memahami konsep sains apa yang sedang ia pelajari, dengan begitu guru dapat mencapai target sesuai dengan tujuan pembelajaran sains pada saat itu (Barenthien et al., 2018; Taridi, M. \& Dono, 2019).

Pembelajaran sains yang dilakukan oleh guru berdasarkan pengamatan peneliti terlihat sudah menerapkan kompetensi inti pendekatan saintifik sebagaimana yang dicantumkan dalam (Permendikbud Indonesia Nomor 146, 2014), diantaranya; mengamati dengan indera, menanya, mengumpulkan informasi, menalar, dan mengomunikasikan. Adapun penjelasannya akan dijabarkan pada tabel 1.

Tabel 1. Strategi Guru dalam Upaya Pemahaman Konsep Sains Anak Kelompok B

\begin{tabular}{|c|c|c|}
\hline No. & $\begin{array}{c}\text { Kompetensi } \\
\text { Inti }\end{array}$ & Strategi Guru \\
\hline 1. & Pengamatan & $\begin{array}{l}\text { Saat melakukan percobaan sains tentang "hujan warna", anak } \\
\text { menggunakan indera penglihatannya untuk mengamati macam-macam } \\
\text { alat dan bahan eksperimen Alat dan bahan yang dibutuhkan, seperti; } \\
\text { gelas berisi air, minyak, pewarna makanan, dan sendok. Anak diberi } \\
\text { kesempatan untuk menggunakan indera peraba (jari-jari tangan) mereka } \\
\text { agar dapat merasakan perbedaan masing-masing benda cair seperti air, } \\
\text { minyak, dan pewarna makanan. Selain itu anak juga diberi kesempatan } \\
\text { untuk menggunakan indera penciuman mereka guna membedakan } \\
\text { macam-macam bau dari benda cair tersebut. Pada kegiatan ini guru } \\
\text { tidak memfokuskan pada indera pengecap (lidah) dan indera } \\
\text { pendengaran. }\end{array}$ \\
\hline 2. & Menanya & $\begin{array}{l}\text { Pada langkah pertama saat melakukan eksperimen, saat guru } \\
\text { mencampur beberapa tetes pewarna makanan ke dalam wadah yang } \\
\text { berisi minyak, guru bertanya kepada anak, "mengapa warna minyaknya } \\
\text { bisa berubah?", rata-rata anak hampir bisa menjawab pertanyaan } \\
\text { tersebut. Untuk memperjelas pemahaman anak, maka guru menjelaskan } \\
\text { bahwa perubahan warna minyak terjadi karena minyak sudah } \\
\text { bercampur dengan pewarna makanan. Langkah kedua, guru }\end{array}$ \\
\hline
\end{tabular}




\begin{tabular}{|c|c|c|}
\hline No. & $\begin{array}{c}\text { Kompetensi } \\
\text { Inti } \\
\end{array}$ & Strategi Guru \\
\hline & & $\begin{array}{l}\text { memasukkan minyak yang telah bercampur warna tersebut ke dalam } \\
\text { gelas yang berisi air. Anak terkejut dengan proses yang terjadi dan } \\
\text { bertanya kepada guru, mengapa minyak tidak bisa menyatu dengan air } \\
\text { saat digabungkan, dan yang terjadi justru minyak mengambang di atas } \\
\text { permukaan air. Dalam upaya ini, guru memberi kesempatan terlebih } \\
\text { dahulu kepada anak lain untuk menjawab pertanyaan temannya, } \\
\text { kemudian barulah guru menjelaskan bahwa air dan minyak itu memiliki } \\
\text { sifat yang berbeda, jadi kalau diibaratkan seperti manusia mereka tidak } \\
\text { saling berteman/bermusuhan karena memiliki hobi yang berbeda. } \\
\text { Misalnya Amira tidak berteman dengan Putri karena Putri menyukai } \\
\text { permainan perosotan, sedangkan Amira lebih menyukai permainan } \\
\text { ayunan. Seperti itulah ibaratnya air dan minyak, mereka tidak bisa } \\
\text { bersatu. Penting membangun pemahaman konsep sains anak dengan } \\
\text { memberi kesempatan kepada mereka untuk bereksplorasi melalui } \\
\text { kegiatan-kegiatan sains yang menarik dan menantang, sehingga anak- } \\
\text { anak dapat berpartisipasi secara aktif (Wulandari et al., 2019). }\end{array}$ \\
\hline 3. & $\begin{array}{l}\text { Mengumpulkan } \\
\text { Informasi }\end{array}$ & $\begin{array}{l}\text { Berdasarkan hasil pengamatan dan berbagai penjelasan dari orang } \\
\text { dewasa disekitarnya, anak menyerap berbagai pengetahuan baru yang } \\
\text { ia dapatkan kemudian akan menyesuaikannya dengan pengalaman } \\
\text { yang pernah ia dapatkan sebelumnya. Dalam hal ini, guru memberi } \\
\text { kesempatan kepada anak untuk menyampaikan pengalamannya yang } \\
\text { berhubungan dengan percobaan yang sedang dilakukan. Guru juga } \\
\text { membuka kesempatan kepada anak untuk lebih terbuka dalam } \\
\text { menyampaikan ide dan pendapatnya. }\end{array}$ \\
\hline 4. & Menalar & $\begin{array}{l}\text { Anak mencoba menggunakan kemampuannya untuk menghubungkan } \\
\text { pengalamannya dengan hasil percobaan sains yang telah ia lakukan. } \\
\text { Pada percobaan "hujan warna" tersebut, anak mendapati hasil dari } \\
\text { pengamatannya bahwa minyak yang mengambang di atas permukaan } \\
\text { air bisa tenggelam ke bawah permukaan. Kemudian anak juga } \\
\text { mengamati proses jatuhnya ternyata tidak langsung berjatuhan } \\
\text { serempak, melainkan minyak membentuk menjadi butiran kecil seperti } \\
\text { air hujan dan jatuh perlahan-lahan dari setiap posisi. }\end{array}$ \\
\hline 5. & Mengomunikasikan & $\begin{array}{l}\text { Guru meminta anak untuk bercerita kepada teman-temannya apa yang } \\
\text { bisa ia sampaikan dari hasil percobaannya, mulai dari menyebutkan alat } \\
\text { dan bahan, langkah-langkahnya, hingga ke proses percobaan. Kemudian } \\
\text { menjelaskan kesimpulan dari temuannya, contohnya salah satu anak } \\
\text { menyimpulkan seperti ini, "hujan itu ternyata bisa kita buat sendiri } \\
\text { teman-teman". Maksudnya adalah hujan bisa dimanipulasi dengan } \\
\text { percobaan sederhana menggunakan alat dan bahan yang ada. }\end{array}$ \\
\hline
\end{tabular}

Berdasarkan hasil observasi dan wawancara dengan guru, peneliti menyimpulkan bahwa dibalik pemahaman konsep sains yang diterima anak, ada dukungan penuh dari keterlibatan orang tua dalam prosesnya. Oleh karena itu, peneliti tidak hanya meninjau dari strategi guru, tetapi juga meninjau keterlibatan orang tua yang menjadi faktor utama dalam pengawasan dan bimbingan anak saat melakukan percobaan melalui pembelajaran daring.

\section{Keterlibatan Orang Tua dalam Upaya Pemahaman Konsep Sains Anak}

Keterlibatan orang tua mencakup banyak hal untuk keberhasilan akademik anak mereka, termasuk diantaranya; keterlibatan orang tua dalam pendidikan dan masalah sekolah anak, partisipasi orang tua dalam berbagai kegiatan sekolah, keterlibatan orang tua dalam pengambilan keputusan tentang sekolah, komunikasi antara orang tua dengan guru tentang perkembangan anak, bahkan pengawasan orang tua di rumah termasuk pembelajaran tentang keterampilan praktis sehari-hari (McDowell et al., 2018). 
Saat situasi pandemi, kebanyakan kantor dan sekolah ditutup sementara sehingga sistem kerja dan belajar siswa harus di lakukan dari jarak jauh. Dalam kesempatan ini, orang tua seharusnya bisa memanfaatkan kebersamaannya dengan anak di rumah untuk memberi pendampingan yang lebih intens dalam belajar. Pada praktik kegiatan sains, anak membutuhkan tempat untuk mengerahkan semua pertanyaan yang muncul di dalam pikirannya. Atas dasar tersebut, orang tua harus mampu mendorong anak untuk bertanya, mengungkapkan pendapatnya, dan memberi kesempatan anak untuk berpikir dalam mengambil keputusan, menurut Hayati (2011) dalam (Irma et al., 2019) ini merupakan cara orang tua dalam menunjang potensi anak.

Dalam kebanyakan kasus, Wade \& Moore (1998) dalam (Fasina \& Fagbeminiyi, 2011) mengatakan anak yang memiliki prestasi secara akademis lebih sering ditemukan memiliki orang tua yang tertarik pada pembelajaran anak-anak mereka dan selalu ingin terlibat dalam kegiatan pembelajaran yang mendukung. Memang semua orang tua pada dasarnya menginginkan anak mereka sukses di kemudian hari, namun tidak semua orang tua mengetahui cara yang efektif dalam hal ini. Akibatnya muncul rasa tidak percaya diri orang tua dalam mengasuh anaknya, padahal rasa percaya diri orang tua sebagaimana yang disebutkan dalam (Durisic \& Bunujevac, 2017) terbukti menjadi faktor yang paling kuat untuk pengasuhan yang efektif. orang tua dengan rasa percaya diri (self-efficacy) yang tinggi umumnya lebih optimis dan konsisten dalam berinteraksi dengan anak mereka dibandingkan orang tua dengan self-efficacy yang lebih rendah. Untuk memecahkan masalah ini, orang tua bisa bekerja sama dengan guru untuk memantau perkembangan anaknya, misalnya guru melaporkan perkembangan anak di sekolah pada semua aspek perkembangannya, sehingga orang tua mengetahui bagaimana perkembangan anaknya dan permasalahan apa yang mungkin terjadi dan mempengaruhi akademis atau perilaku sosial anak. Begitu juga sebaliknya, orang tua harus melaporkan bagaimana perkembangan anaknya di rumah agar permasalahan yang menyangkut perkembangan anak bisa segera teratasi dengan penanganan yang tepat.

Dengan demikian, dapat dipahami bahwa pentingnya keterlibatan orang tua pada pembelajaran anak khususnya dalam upaya pemahaman konsep sains. Pembelajaran sains dianggap penting karena peristiwa alam di sekitar kita sangat kompleks dan mengandung konsep ilmiah yang tidak terbatas. Sehingga penting bagi orang tua untuk mendorong anak untuk memahami setiap konsep dari pembelajaran sains itu sendiri. Pada intinya, perkembangan anak tidak akan maksimal tanpa adanya keterlibatan orang tua. Begitu juga dengan proses belajar-mengajar di sekolah, guru tidak bisa berdiri sendiri menangani masalah perkembangan anak. Masing-masing anak mempunyai karakter yang berbeda dan unik, oleh karena itu dibutuhkan kerja sama yang baik antara guru dan orang tua untuk dapat menyeimbangkan stimulus dalam mengembangkan potensi anak.

\section{SIMPULAN}

Pemahaman konsep sains anak di TK Islam Al-Azhar 41 sudah menunjukkan adanya perkembangan. Hal ini dikarenakan adanya dukungan guru dalam merancang strategi persiapan sebelum menerapkan pembelajaran sains, seperti; mengadakan kegiatan sosialisasi dengan orang tua dalam mempersiapkan kebutuhan kegiatan eksperimen anak; melakukan briefing jauh hari sebelum melakukan percobaan dengan cara mempelajari berbagai tutorial video sains sebagai referensi dalam menambah wawasan guru. Begitu pun dengan orang tua, lebih dari $50 \%$ orang tua terlibat dalam pembelajaran sains anak, mulai dari persiapan, proses, dan evaluasi kegiatan sains.

\section{UCAPAN TERIMAKASIH}

Rasa terimakasih kami ucapkan kepada guru-guru dan orang tua TK Islam Al-Azhar yang telah membantu dalam pengumpulan data pada penelitian ini sehingga berjalan dengan lancar, serta ucapan terimakasih kepada semua pihak Jurnal Obsesi Pendidikan Anak Usia Dini atas masukan dan sarannya untuk perbaikan artikel ini hingga menjadi bacaan yang berkualitas. 


\section{DAFTAR PUSTAKA}

Adbo, K., \& Vidal Carulla, C. (2020). Learning About Science in Preschool: Play-Based Activities to Support Children's Understanding of Chemistry Concepts. International Journal of Early Childhood, 1-19. https://doi.org/10.1007/s13158-020-00259-3

Akçay, N. O. (2016). Determining the Views and Adequacy of the Preschool Teachers Related to Science Activities. Universal Journal of Educational Research, 4(4), 821-829. https://doi.org/10.13189/ujer.2016.040419

Barenthien, J., Lindner, M. A., \& Ziegler, T. (2018). Exploring Preschool Teachers' Science Specific Knowledge. $\quad$ Early Years, $1-16$. https://doi.org/10.1080/09575146.2018.1443321

Broström, S. (2015). Science in Early Childhood Education. Journal of Education and Human Development, 4(2(1)), 107-124. https://doi.org/10.15640/jehd.v4n2_1a12

Bulunuz, M. (2013). Teaching Science Through Play in Kindergarten: Does Integrated Play and Science Instruction Build Understanding?. European Early Childhood Education Research Journal, 21(2), 226-249. https:/ / doi.org/10.1080/1350293X.2013.789195

Bustamante, A. S., White, L. J., \& Greenfield, D. B. (2018). Approaches to Learning and Science Education in Head Start: Examining Bidirectionality. Early Childhood Research Quarterly, 44, 34-42. https://doi.org/10.1016/j.ecresq.2018.02.013

Dogan, Y. \& Simsar, A. (2018). Preschool Teachers' Views on Science Education, the Methods They Use, Science Activities, and the Problems They Face. International Journal of Progressive Education, 14(5), 57-76. https://doi.org/10.29329/ijpe.2018.157.6

Durisic, M., \& Bunujevac, M. (2017). Parental Involvement as a Important Factor for Successful Education. CEPS Journal, 7(3), 137-153. https:// files.eric.ed.gov/fulltext/EJ1156936.pdf

Fasina, B., \& Fagbeminiyi, F. (2011). The Role of Parents in Early Childhood Education: A Case Study of Ikeja, Lagos State, Nigeria. Type: Double Blind Peer Reviewed International Research Journal, 11(2).

Furwati, S., Sutopo, \& Zubaidah, S. (2017). Conceptual Understanding and Representation Quality on Newton's Laws through Multi-Representation Learning. Jurnal Pendidikan Sains, 5(3), 80-88.

Gerde, H. K., et al. (2013). Using the Scientific Method to Guide Learning: An Integrated Approach to Early Childhood Curriculum. Early Childhood Education Journal, 41, 315323. https:// doi.org/10.1007/s10643-013-0579-4

Guo, Ying, et al. (2015). Exploring Preschool Children's Science Content Knowledge. Early Educ Dev., 26(1), 125-146. https:/ / doi.org/10.1080/10409289.2015.96824 0

Gustavsson, L., et al. (2016). Ways of Dealing with Science Learning: A Study Based on Swedish Early Childhood Education Practice. International Journal of Science Education, 38(11), 1867-1881. https:// doi.org/10.1080/09500693.2016.1220 650

Hong, S.-Y., \& Karen E. Diamond. (2012). Two Approaches to Teaching Young Children Science Concepts, Vocabulary, and Scientific Problem - Solving Skills. Early Childhood Research Quarterly, 27, 295-305. https://doi.org/10.1016/j.ecresq.2011.09.006

Irma, C. N., Nisa, K., \& Sururiyah, S. K. (2019). Keterlibatan Orang Tua dalam Pendidikan Anak Usia Dini di TK Masyithoh 1 Purworejo. Jurnal Obsesi: Jurnal Pendidikan Anak Usia Dini, 3(1), 214-224. https:// doi.org/10.31004/obsesi.v3i1.152

Kavalari, P., et al. (2012). Contemporary Teaching Methods and Science Content Knowledge in Preschool Education: Searching for Connections. Procedia Social and Behavioral Sciences, 1-6.

Khaeriyah, E., Saripudin, A., \& Kartiyawati, R. (2018). Penerapan Metode Eksperimen dalam Pembelajaran Sains untuk Meningkatkan Kemampuan Kognitif Anak Usia Dini. Awlady: Jurnal Pendidikan Anak, 4(2), 102-119.

Kuru, N \& Akman, B. (2017). Examining the Science Process Skills of Preschoolers with 
Regards to Teachers' and Children' Variables. Education and Science, 42(190), 269-279. https:// doi.org/10.15390/EB.2017.6433

McDowell, K., Jack, A., \& Compton, M. (2018). Parent Involvement in Pre-Kindergarten and the Effects on Student Achievement. The Advocate, 23(6). https:/ / doi.org/10.4148/2637-4552.1004

McMillan, J. H., \& Schumacher, S. (2001). Research in Education. New York: Addison Welsey Longman, Inc.

Mills, S. (2016). Conceptual Understanding: A Concept Analysis. The Qualitative Report, 21(3), 546-557. https://nsuworks.nova.edu/tqr/vol21/iss3/8

Mustofa, B. (2016). Dasar-Dasar Pendidikan Anak Pra Sekolah. Yogyakarta: Parama Ilmu.

Nurkholisoh, D. (2020). Science Concepts in Early Childhood Education. The 2nd International Conference on Elementary Education, 2(1), 1044-1053.

Olcer, S. (2017). Science Content Knowledge of 5-6 Year Old Preschool Children. International Journal of Environmental and Science Education, 12(2), 143-175.

Permendikbud Indonesia Nomor 146. (2014). Kurikulum 2013 Pendidikan Anak Usia Dini. Jakarta: Menteri Pendidikan.

Prasojo, L. D. (2018). Manajemen Strategi. Yogyakarta: UNY Press.

Qonita, E. S. \& Mulyana, E. H. (2017). When Science Becomes an Approach in Early Learning: Know it, Understand it and Do it!. Journal of Nusantara Studies (JONUS), 2(2), 98-106. https:// doi.org/10.24200/jonus.vol2iss2pp98-106

Saçkes, M. (2012). How Often Do Early Childhood Teachers Teach Science Concepts? Determinants of the Frequency of Science Teaching in Kindergarten. European Early Childhood Education Research Journal, 22(2), 169-184. https:// doi.org/10.1080/1350293X.2012.704305

Siagian, S. P. (2004). Manajemen Strategi. Jakarta: Bumi Aksara.

Smolleck, L., \& Hershberger, V. (2011). Playing with science: An investigation of young children's science conceptions and misconceptions. Current Issues in Education, 14(1), 1-31.

Taridi, M. \& Dono, A. (2019). The Kindergarten Teachers' Pedagogical Competences: A Case Study. Indonesian Research Journal in Education |IRJE|, 3(1), 107-119. https:// doi.org/10.22437/irje.v3i1.6737

Widiyatmoko, A., \& Shimizu, K. (2018). An Overview of Conceptual Understanding in Science Education Curriculum in Indonesia. Journal of Physics: Conference Series, 983, 1-6. https:/ / doi.org/10.1088/1742-6596/983/1/012044

Wulandari, C., Sunarso, A., \& Mulyono, S. E. (2019). An Analysis of The Study Scientific Approach Implementation to Develope The Active Learning of Science in The Early Childhood. Journal of Primary Education, 10(1), 55-63.

Yamin, M., \& Sanan, J. S. (2013). Panduan PAUD: Pendidikan Anak Usia Dini. Jakarta: Referensi. 